TITLE:

\title{
Identification of novel genetic markers and evaluation of genetic structure in a population of Japanese crested ibis.
}

\section{AUTHOR(S):}

Tsubono, Kanako; Taniguchi, Yukio; Matsuda, Hirokazu; Yamada, Takahisa; Sugiyama, Toshie; Homma, Kosuke; Kaneko, Yoshinori; Yamagishi, Satoshi; Iwaisaki, Hiroaki

\section{CITATION:}

Tsubono, Kanako ... [et al]. Identification of novel genetic markers and evaluation of genetic structure in a population of Japanese crested ibis.. Animal science journal 2013, 85(4): 356-364

\section{ISSUE DATE:}

2013-12-12

URL:

http://hdl.handle.net/2433/198725

\section{RIGHT:}

This is the peer reviewed version of the following article: Tsubono, K., Taniguchi, Y., Matsuda, H., Yamada, T., Sugiyama, T., Homma, K., Kaneko, Y., Yamagishi, S. and Iwaisaki, H. (2014), Identification of novel genetic markers and evaluation of genetic structure in a population of Japanese crested ibis. Animal Science Journal, 85: 356-364, which has been published in final form at http://dx.doi.org/10.1111/asj.12155.; この論文は出版社版でありません。引用の際には出版社 版をご確認ご利用ください。; This is not the published version. Please cite only the published version. 
1 Identification of novel genetic markers and evaluation of genetic structure in the

2 Japanese population of the Japanese crested ibis

3

4 Kanako TSUBONO, ${ }^{1}$ Yukio TANIGUCHI, ${ }^{1}$ Hirokazu MATSUDA, ${ }^{1}$ Takahisa

5 YAMADA, ${ }^{2}$ Toshie SUGIYAMA, ${ }^{2}$ Kosuke HOMMA, ${ }^{3}$ Yoshinori KANEKO, ${ }^{4}$ Satoshi

6 YAMAGISHI $^{5}$ and Hiroaki IWAISAKI ${ }^{1}$

7

$8{ }^{1}$ Laboratory of Animal Breeding and Genetics, Graduate School of Agriculture, Kyoto

9 University, Sakyo-ku, Kyoto 606-8502, Japan, ${ }^{2}$ Department of Agrobiology, Faculty of 10 Agriculture, Niigata University, Nishi-ku, Niigata 950-2181, Japan, ${ }^{3}$ Field Center for 11 Sustainable Agriculture and Forestry, Niigata University, Nishi-ku, Niigata 950-2181, 12 Japan, ${ }^{4}$ Sado Japanese Crested Ibis Conservation Center, Niibo Sado 952-0101, Japan, 13 and ${ }^{5}$ Yamashina Institute for Ornithology, Abiko, Chiba 270-1145, Japan

15 Correspondence: Hiroaki Iwaisaki, Laboratory of Animal Breeding and Genetics, 16 Graduate School of Agriculture, Kyoto University, Sakyo-ku, Kyoto 606-8502, Japan. Tel: +81-75-753-6322, Fax: +81-75-753-6340, e-mail: iwaisaki@kais.kyoto-u.ac.jp 


\section{ABSTRACT}

Japanese population of the Japanese crested ibis Nipponia nippon was founded by 5 individuals gifted from the People's Republic of China. In order to exactly evaluate genetic structure, we first performed development of novel genetic makers using 89 microsatellite primer pairs of related species for cross-amplification. Of them, only 3 primer pairs were useful for the genetic markers. Additionally, we sequenced allelic PCR products of these 3 markers together with 10 markers identified previously. Most markers showed typical microsatellite repeat units, but 2 markers were not simple microsatellites. Moreover, over half of the markers did not have the same repeat units as those of the original species. These results suggested that development of novel genetic markers in this population by cross-amplification is not efficient, partly because of low genetic diversity. Furthermore, the cluster analysis by STRUCTURE program using 17 markers showed that the 5 founders were divided into 2 clusters. However, the genetic relationships among the founders indicated by the clustering seemed to be questionable, because the analysis relied largely on a small number of triallelic markers, in spite of addition of the 3 useful markers. Therefore, more efficient methods for identifying large numbers of single nucleotide polymorphisms are desirable.

Key words: cross-amplification, genetic diversity, microsatellite, Nipponia nippon 


\section{INTRODUCTION}

The Japanese crested ibis Nipponia nippon was a popular bird in East Asia until the early 20th century, but nowadays, it is considered to be an endangered species due to overhunting or reduction in available habitats (IUCN 2012). In Japan, the Japanese crested ibis in the wild was extinct. After the extinction, 5 individuals (2 individuals in 1999, 1 individual in 2000, and 2 individuals in 2007) were introduced from the People's Republic of China. As a result of the conservation efforts for captive-breeding programs implemented at the Sado Japanese Crested Ibis Conservation Center, Niigata, Japan, the number of the captive individuals at present are about 180 and about 90 individuals have been released in the Sado island.

In the case of small captive-breeding populations for the conservation of the endangered species, it is important not only to increase the population size, but also to prevent increase in inbreeding coefficient and loss of genetic diversity which cause diminution of future adaptability to changing environment and reduction in the average individual fitness (Lande 1988). Moreover, inbreeding depression results in reduction in population growth rate and increase in extinction risk (Frankham \& Ralls 1998). Therefore, the exact knowledge of the current genetic diversity and structure can lead to prevention of genetic deterioration, and be vital to the administration of captive populations and fundamental to the success of metapopulation management strategies, including the reintroduction of captive-bred individuals into the wild.

Historically, pedigree information has been utilized to understand the genetic diversity and structure in captive populations (Ballou \& Foose 1995). However, Henkel et al. (2012) has recently reported that pedigree knowledge alone is not sufficient for the exact understanding of the genetic diversity and structure, under the situation that the founders of the captive population are related to each other. The Japanese population of the Japanese crested ibis is applicable to this situation. Therefore, molecular genetic as 
1 well as pedigree information are needed to assess the genetic diversity or infer the

2 structure of the population.

3

4

Among various molecular markers, microsatellite DNA, which is simple repetitive sequences present widely throughout eukaryote organisms and have high levels of polymorphism (Jarne \& Lagoda 1996; Zhang \& Hewitt 2003), is one of the most useful DNA markers for the study on the genetic diversity and structure (Zhang \& Hewitt 2003). For the Japanese crested ibis, 24 microsatellite markers were developed (Ji et al. 2004; He et al. 2006), and 9 of these markers were polymorphic in the Japanese population (Urano et al. 2013). Microsatellite PCR primer pairs derived from one species are often found to amplify microsatellite loci in related species (Engel et al. 1996; Primmer et al. 1996; Slate et al. 1998). Especially, cross-amplifying markers might be worthwhile for bird studies, since the avian genome has been shown to contain fewer microsatellites than organisms of other classifications (Primmer et al. 1997). We previously showed the polymorphisms of 10 markers developed for related species (1 from the wood stork, 1 from the roseate spoonbill, and 8 from the black-faced spoonbill) in the Japanese population and performed the assessment of genetic diversity and the inference of population structure using a total of 19 markers (Urano et al. 2013). Simulation studies showed that increasing the number of loci used improved the inference of the population structure (Evanno et al. 2005; Hubisz et al. 2009). Thus, in this study, in order to exactly evaluate genetic structure, we first attempted to identify new genetic markers useful for the Japanese population using microsatellite primers developed in the related species. Subsequently, we used the whole of useful markers identified in the present and previous studies to assess the genetic diversity and infer the genetic structure of the Japanese population.

\section{MATERIALS AND METHODS}


1 Sample

2

3

We used the 5 founder birds for the Sado captive Japanese crested ibis population, and 138 descendant birds of which 77 individuals were alive in Japan and 61 were dead or returned to the People's Republic of China by 2011. The descendant birds had hatched from 2001 to 2009. For the founder birds, blood samples were collected from the founders at the Sado Japanese Crested Ibis Conservation Center (Niigata, Japan) and used for genomic DNA preparation. For the descendant birds, the post-hatch eggs stored at the Sado Japanese Crested Ibis Conservation Center were used. The vascularized chorioallantois membrane samples were excised from the eggs and used for genomic DNA preparation, as described by Urano et al. (2011). In addition to these samples, we used the liver sample of a dead individual for the examination of PCR amplification. DNA was extracted from these samples using the DNeasy Blood \& Tissue Kit (QIAGEN, Hilden, Germany).

\section{PCR amplification and length polymorphism detection}

We used 42, 8, 12, 1, 7, 9, and 10 microsatellite primer pairs developed for the humboldt penguin (Spheniscus humboldti) (Ohta A, 2010, unpublished data), the little penguin (Eudyptula minor) (Billing et al. 2007), the yellow-eyed penguin (Megadyptes antipodes) (Boessenkool et al. 2008), the african penguin (Spheniscus demersu) (Akst et al. 2002, we used only B3-2 marker for the african penguin), the white stork (Ciconia ciconia) (Shephard et al. 2009), the american white pelican (Pelecanus erythrorhynchos) (Hickman et al. 2008), and the great white pelican (Pelecanus onocrotalus) (De Ponte Machado et al. 2009), respectively. These bird species were considered as the related species to the Japanese crested ibis, according to 
1 Sibley-Ahlquist taxonomy of birds (Sibley \& Ahlquist 1990). The information on these primer pairs were also obtained from the literatures published up to 2009. All forward primers included the universal sequence (TGTAAAACGACGGCCAGT) at 5' end. Firstly, we examined PCR amplifications of these primer pairs with DNA of a dead individual. PCR reactions were performed using a $20 \mu \mathrm{L}$ final volume containing $20 \mathrm{ng}$ genomic DNA, $0.4 \mu \mathrm{mol} / \mathrm{L}$ each of primers, $0.2 \mathrm{mmol} / \mathrm{L}$ each of dNTPs, $1 \times E x$ taq buffer (Takara, Shiga, Japan), and 0.5 U Ex Taq DNA polymerase (Takara) with the following temperature profile: an initial denaturation step at $94^{\circ} \mathrm{C}$ for $5 \mathrm{~min}$, and then 35 cycles of denaturing at $94^{\circ} \mathrm{C}$ for $30 \mathrm{~s}$, annealing at $55^{\circ} \mathrm{C}$ for $30 \mathrm{~s}$, and extension at $72^{\circ} \mathrm{C}$ for 1 min. PCR products were run on a $2 \%$ agarose gel and we selected the primer pairs which showed a single band with a length less than 500 bp. Secondly, to detect length polymorphisms in PCR products from the primer pairs, DNA panel of the 5 founders were tested using 2 rounds of PCR amplification. The first-round amplifications were carried out under the same condition as above. We performed second-round amplifications using the first-round PCR products as the template DNA and universal sequence fluorescently end-labeled with 6-FAM as the forward primer. PCR reactions were performed using a $20 \mu \mathrm{L}$ final volume containing $1 \mu \mathrm{L}$ PCR products, $0.4 \mu \mathrm{mol} / \mathrm{L}$ each of primers, $0.2 \mathrm{mmol} / \mathrm{L}$ each of dNTPs, $1 \times E x$ taq buffer (Takara) and $0.5 \mathrm{U} E x$ Taq DNA polymerase (Takara) with the following temperature profile: an initial denaturation step at $94^{\circ} \mathrm{C}$ for $5 \mathrm{~min}$, and 30 cycles of denaturing at $94^{\circ} \mathrm{C}$ for $30 \mathrm{~s}$, annealing at $53^{\circ} \mathrm{C}$ for $45 \mathrm{~s}$, and extension at $72^{\circ} \mathrm{C}$ for $45 \mathrm{~s}$, followed by a final extension step at $72^{\circ} \mathrm{C}$ for $10 \mathrm{~min}$. For determining sizes of the PCR products, a portion of PCR products $(1 \mu \mathrm{L})$ was combined with $10 \mu \mathrm{L}$ of formamide loading dye that contained the fluorescent labeled GeneScan-500LIZ size standard (Applied Biosystems, Foster city, CA), and resolved on the 3730xl DNA analyzer (Applied Biosystems). We used GeneMapper software version 4.0 (Applied Biosystems) to score the PCR products. The 
1 primer pairs showing polymorphisms among the 5 founders were ascertained the

2 effectiveness as genetic markers by comparing the genotypes of individuals with

3 Mendelian parent-offspring relationships. Subsequently, the markers which were

4 seemed to be effective were genotyped on the descendants.

5

6 Validation of polymorphic markers as microsatellites

7

8

We sequenced the polymorphic markers identified in this study and the 10 related species markers identified in the previous study (Urano et al. 2013) and examined the differences in the sequence among PCR products of different size. PCR amplifications were carried out on the same condition as in the examination of amplification, except for the temperature profile for the previously identified markers, which followed the protocols described by He et al. (2006), Sawyer and Benjamin (2006), Tomasulo-Seccomandi et al. (2003), and Yeung et al. (2009). The PCR products were examined by electrophoresis through a $2 \%$ agarose gel to determine the quality and quantity for DNA sequencing. DNA sequencing of PCR products was performed by direct sequencing following excision from the gel. Alternatively, the PCR products were cloned into TA cloning vector pCR2.1-TOPO (Invitrogen, Carlsbad, CA) and at least 2 positive clones were sequenced. Sequencing was carried out by Greiner Japan Co., Ltd. (Tokyo, Japan). Sequence alignments and comparisons were made with GENETYX version 10 (Software Development, Tokyo, Japan). Nucleotide polymorphisms were identified by comparison of sequence traces between the PCR products of different size.

\section{Data analysis}


1 studies, basic genetic diversity parameters including allelic diversity (A; Fernández et al.

2 2005), effective number of alleles $\left(n_{e}\right)$, observed heterozygosity $\left(H_{0}\right)$, unbiased

3 expected heterozygosity ( $\mathrm{H}_{\mathrm{E}}$; Nei 1987), and polymorphic information content (PIC;

4 Boststein et al. 1980) of the Japanese population were estimated using EXCEL

5 MICROSATELLITE TOOL KIT version 3.1.1 (Park 2001). The deviation from

6 Hardy-Weinberg equilibrium (HWE) at each locus was tested using a Markov-chain

7 algorithm (Guo \& Thompson 1992) in GENEPOP version 4.0 (Raymond \& Rousset

8 1995). All pairs of loci were also tested for genotypic linkage disequilibrium using the

9 exact test in GENEPOP version 4.0. The sequential Bonferroni adjustment (Rice 1989)

10 was applied to correct for multiple testing of deviation from HWE and linkage

11 disequilibrium.

To investigate the genetic structure of the population, program STRUCTURE version 2.3 (Pritchard et al. 2000) was used. Since we found that different runs could produce different likelihood values, 10 runs were carried out for each data set in order to quantify the amount of variation of the likelihood for each $\mathrm{K}$, or the number of clusters. The range of possible Ks we tested was from 1 to 8 . Runs with a burn-in period of 100,000 followed by 100,000 MCMC iterations were performed, using the model with correlated allele frequencies and assuming admixture (Falush et al. 2003). The $\alpha$, or the Dirichlet parameter for the degree of admixture, was the same for all clusters and allowed to vary between runs. For each value of $\mathrm{K}$, the log-likelihood values of the data defined as $\ln \operatorname{Pr}(\mathrm{X} / \mathrm{K})$ (Pritchard et al. 2000) were averaged and standard deviation was calculated. We tried to infer the appropriate $\mathrm{K}$ by comparing both the averaged $\ln$ $\operatorname{Pr}(\mathrm{X} / \mathrm{K})$ and calculated $\Delta \mathrm{K}$ statistic (Evanno et al. 2005). This procedure was repeated 3 times. Additionally, the same analysis was carried out, using the subsets of markers in order to investigate the influence of the marker sets used on STRUCTURE results. 
1

\section{RESULTS}

\section{Identification of novel useful marker}

Of the 89 primer pairs (Billing et al. 2007; Boessenkool et al. 2008; Hickman et al. 2008; De Ponte Machado et al. 2009; Shephard et al. 2009; Ohta A, 2010, unpublished data), 25 (13 from the humboldt penguin, 3 from the american white pelican, 5 from the white stork, and 4 from the great white pelican) succeeded in amplifying (out of the other 64 primer pairs, 18 showed multiple bands, but 46 showed no PCR products). Out of the 25 primer pairs, 4 (hSTR1-78, hSTR1-92 and hSTR1-150; from the humboldt penguin, and PEL086; from the great white pelican) had PCR products with different size among the 5 founders (Table 1). Remaining 21 loci amplified as a monomorphic microsatellite product in this study: hSTR1-56, hSTR1-102， hSTR1-109， hSTR1-139， hSTR1-162，hSTR1-233， hSTR1-268, hSTR1-308, hSTR1-312, and hSTR1-344 from the humboldt penguin, PeEr03, PeEr05, and PeEr06 from the american white pelican, Cc01, Cc02, Cc05, Cc06, and Cc07 from the white stork, and PEL149, PEL207, and PEL304 from the great white pelican. We should note that all the 5 founders had the same hetero-genotypes at each of 2 primer pairs (hSTR1-78 and hSTR1-92). To ascertain whether the 4 primer pairs are useful as genetic markers, the PCR products were genotyped using DNA from individuals with Mendelian parent-offspring relationships. As a result, we obtained the genotypes consistent with Mendelian parent-offspring relationships at 3 primer pairs (hSTR1-78, hSTR1-150, and PEL086), but that was not the case at 1 primer pair (hSTR1-92) where all the individuals showed the same hetero-genotypes (data not shown). Thus, the 3 polymorphic markers were chosen for large-scale genotyping of the 138 descendants for the exact analysis of genetic diversity and structure in this study. 
1 previous study, we sequenced allelic PCR products of different size. Of the 13 markers,

211 had repeat regions and there were differences in the number of repeat unit among

3 each allele, while 2 markers did not seem to be simple microsatellite markers (Table 2,

4 Fig. 1). There were three and one partial differences in sequences between alleles of

$5 \quad$ PM1-17 and PM2-37 loci, respectively, and the variations of single nucleotide were

6 considered to be sequencing errors or single nucleotide polymorphisms. For the 11

7 markers which had simple repeat regions, comparing the sequences of repeat motifs

8 with those of original species, we found that 6 had the same repeat motifs as those of

9 the original species, whereas 5 had different sequences from the original species.

11 Analysis of genetic diversity

The genetic diversity parameters were shown in Table 3 . The values of the first 19 markers were cited from Urano et al. (2013), but slightly different values were obtained because we recalculated them excluding some data which were inconsistent with Menderian parent-offspring relationships probably because of typing error. The 3 useful markers identified in this study had 7 alleles in total (3 alleles at PEL086 locus and 2 alleles each at hSTR1-78 and hSTR1-150 loci). For the whole of 22 useful markers (3 identified here and 19 identified previously), average A was 2.18 in both the founders and descendants and average $n_{e}, H_{E}, H_{O}$, and PIC were 1.73, 0.38, 0.40, and 0.31, respectively. PEL086 locus had the second highest values for these parameters, and hSTR1-78 and hSTR1-150 loci had moderate values. The 77 descendants which are still alive in Japan inherited all alleles of 22 markers from the founders and the genetic diversity measures similar to those of the 138 descendants were obtained (data not shown). The Nn26, NnNF5, and PM2-20 loci and the overall showed a deviation from the HWE $(P<0.05)$ and the NnNF5 locus significantly deviated from HWE even after 
1 sequential Bonferroni correction for multiple testing. The PM2-20 locus may be

2 Z-linked since the locus had Ho lower than expected, and in the original species, or

3 black-faced spoonbill, it was suggested that the marker was Z-linked (Yeung et al.

4 2009). In addition, pairwise tests for genotypic disequilibrium revealed that all the 3

5 markers identified in this study (hSTR1-150, hSTR1-78, and PEL086) were in

6 significant linkage disequilibrium with previous markers (Nn01, PM2-28, and Aaju02)

7 after accounting for multiple testing.

\section{$9 \quad$ Cluster analysis}

For the analyses of the composition of genomes among the founders and the descendants using the program STRUCTURE, we used 17 markers except for the PM2-20 locus which seemed to be Z-linked, NnNF5 locus which showed a significant deviation from HWE even after sequential Bonferroni correction, and hSTR1-150, hSTR1-78, and Aaju02 for the 3 pairs of loci which were in significant linkage disequilibrium. In the program STRUCTURE, the true number of clusters $(\mathrm{K})$ is often identified using the maximal value of $\ln \operatorname{Pr}(\mathrm{X} / \mathrm{K})$ (Ciofi et al. 2002; Vernesi et al. 2003; Hampton et al. 2004). The highest value of $\ln \operatorname{Pr}(\mathrm{X} / \mathrm{K})$ was observed at $\mathrm{K}=2$ for all 3 replicates. Furthermore, the $\Delta \mathrm{K}$ statistic was found to be also obviously maximum at $\mathrm{K}$ $=2$, giving averaged $\Delta \mathrm{K}$ values for 3 replicates of 89.28 at $\mathrm{K}=2,2.01$ at $\mathrm{K}=3,3.79$ at $\mathrm{K}=4,2.66$ at $\mathrm{K}=5,2.68$ at $\mathrm{K}=6$, and 5.56 at $\mathrm{K}=7$. This finding suggested that the Japanese population contains 2 clusters. At $K=2$, as shown in Fig. 2, the 2 clusters were distributed with approximately equal proportion in total and with considerable inter-individual variation, suggesting that the founder genomes were inherited equally in the population and with various admixture patterns at individual level. Given that this population was founded by 5 individuals, the result of only 2 clusters was likely to be 
consistent with a considerably low level of genetic diversity in the Japanese population. We carried out the cluster analysis with the subsets of the 17 markers. The result obtained by excluding the 4 triallelic markers (Nn01, PM2-21, PM2-37, and PM3-13) from the 17 markers was largely different from that of the 17 markers (Fig. 3), giving the highest value of $\ln \operatorname{Pr}(\mathrm{X} / \mathrm{K})$ at $\mathrm{K}=1$. However, inclusion of the 4 triallelic markers, irrespective of the markers chosen, resulted in the result similar to that of the 17 markers. Even if we used the 4 triallelic markers in combination with the 6 biallelic markers which had low PIC values (Nn17, Nn18, PM2-16, PM2-37 PM3-13, and Wsu13), we obtained the similar result at $K=2$ (data not shown). Therefore, it was suggested that the triallelic markers had an essential effect on the clustering result.

\section{Genetic relationships among the founders}

The analysis by STRUCTURE showed that 5 founders were divided into 2 clusters. One cluster contained founder C which was accounted for mostly by dark gray cluster and another cluster contained founder A, B, D, and E that was accounted for mostly by light gray cluster. Furthermore, founder $\mathrm{C}$ was also distinct from the other founders at $K=3$ to 7 . However, the genotype data did not show that there was an apparent difference between the 2 clusters (Table 3). The founder $\mathrm{C}$ had a specific allele for Nn01 and specific genotypes for PM221, hSTR1-150, and PEL086, but over 80\% of the genotypes of founder $\mathrm{C}$ were shared by the other founders. Therefore, the genome of founder C did not seem to be apparently distinct from the others' genomes.

\section{DISCUSSION}

Because the isolation of microsatellite markers is extensive and time-consuming, it is generally efficient to test the cross-amplification of the primer of 
1 the related species (Galbusera et al. 2000). In this study, of the 89 microsatellite markers

2 developed for the related species, 25 were successfully amplified, 4 showed PCR

3 products of different size in the 5 founders, and eventually, only 3 were indicated to be

4 useful as a genetic marker for the Japanese population. In the previous study, 44 out of

5 the 50 markers developed for the related species were successfully amplified and 10

6 showed polymorphisms in the 5 founders (Urano et al. 2013). The proportion of the

7 markers which were successfully amplified or showed polymorphisms in this study was

8 extremely low, as compared with that of the previous study, being consistent with the

9 fact that the related species utilized in this study were evolutionally more distant from

10 the Japanese crested ibis than those of the previous study. The species utilized in this

11 study belong to different families from the Japanese crested ibis, while the most of the species used in the previous study belong to the same family as the Japanese crested ibis

13 (Sibley \& Ahlquist 1990; Urano et al. 2013). It is suggested that the evolutionally more distant the related species used are from the target species, the lower the probability of amplification success or polymorphism detection is (Primmer et al. 1996, 2005). Particularly, in bird species, it was reported that in the case where the related species used belonged to a different family of the same order, the rate of success in amplification (33 $\pm \mathbf{3 \%}$ ) or detection of polymorphisms (28 $\pm \mathbf{6 \%}$ ) was lower than that of the case where they belonged to a different genus of the same family ( $60 \pm 2 \%$ or $43 \pm$ 3\%) (Primmer et al. 2005; Barbará et al. 2007). We should note that it is also difficult to identify new markers in a population with lower genetic diversity such as the population of the Japanese crested ibis.

It is necessary to determine the sequence of alleles in order to validate the genetic markers from the cross-amplification as microsatellite, because it is unclear that the primers amplify the microsatellite sequences in the target species. Thus, we sequenced the alleles of the 3 markers identified in this study and the 10 markers 
1 identified previously by the cross-amplification (Urano et al. 2013). As a result, we

2 found that while 11 markers have tandem repeat sequences, 5 markers have the repeat

3 sequences different from those of the original species. Also, 2 markers were not simple

4 microsatellite. These results suggested that over half of the markers did not amplify orthologous genome regions to the original species.

Using the whole of useful markers identified in the present and previous studies, we calculated genetic diversity parameters in the Japanese population. Although the 3 markers were added and one of those was triallelic, values of the parameters were not much different from the previous study by Urano et al. (2013) and were similar to those of other species with population bottleneck (Bouzat et al. 1998; Tarr et al. 1998). These results, together with the result that the maximum number of alleles at single locus was 3 in spite of the founding by 5 individuals, support our previous idea of a considerably low level of genetic diversity in the Japanese population (Urano et al. 2013).

In the result of the cluster analysis by STRUCTURE, the 5 founders were divided into 2 clusters. On the other hand, comparing the actual genotype data, there was not apparent difference between 2 clusters. Furthermore, by excluding the 4 triallelic markers, the founders were not divided into 2 clusters. These results suggest that the cluster analysis relied largely on more polymorphic markers and the differences in the genotypes of the triallelic markers made a significant contribution to the STRUCTURE result. Thus, the genetic relationships among the 5 founders indicated by the cluster analysis with STRUCTURE using 17 markers seemed to be questionable, because the analysis relied largely on a small number of triallelic markers, in spite of addition of the 3 useful markers. Therefore, development of large numbers of single nucleotide polymorphisms by means of more efficient methods such as those using next generation sequencing technologies and further molecular genetic studies with those markers will be needed for more exact understanding of genetic diversity and 
1 structure in the Japanese population of the Japanese crested ibis. Additionally, for the

2 future conservation management strategy, it is important to investigate not only neutral

3 polymorphisms in microsatellite markers but also functional mutations related to fitness

4 in MHC (Major histocompatibility complex) regions (Kohn et al. 2006; Agudo et al. 5 2011).

6

\section{ACKNOWLEDGEMENTS}

8

We thank Japanese Ministry of the Environment, Sado city, and the Japanese

9 Crested Ibis Project, Center for Transdisciplinary Research, Niigata University, Japan 10 for providing the founds. 


\section{REFERENCES}

Agudo R, Alcaide M, Rico C, Lemus JA, Blanco G, Hiraldo F, Donázar JA. 2011. Major histocompatibility complex variation in insular populations of the Egyptian vulture: inferences about the roles of genetic drift and selection. Molecular Ecology 20, 2329-2340.

Akst EP, Boersma PD, Fleischer RC. 2002. A comparison of genetic diversity between the Galápagos Penguin and the Magellanic Penguin. Conservation Genetics 10, 1033-1036.

Ballou JD, Foose TJ. 1995. Demographic and genetic management of captive populations. In: Kleiman DG (ed), Wild Mammals in Captivity, pp. 263-283. University of Chicago Press, Chicago.

Barbará T, Palma-Silva C, Paggi GM, Bered F, Fay MF, Lexer C. 2007. Cross-species transfer of nuclear microsatellite markers: potential and limitations. Molecular Ecology 16, 3759-3767.

Billing TM, Guay PJ, Peucker AJ, Mulder RA. 2007. Isolation and characterization of polymorphic microsatellite loci for the study of paternity and population structure in the little penguin Eudyptula minor. Molecular Ecology Notes 7, 425-427.

Boessenkool S, King TM, Seddon PJ, Waters JM. 2008. Isolation and characterization of microsatellite loci from the yellow-eyed penguin (Megadyptes antipodes). Molecular Ecology Resources 8, 1043-1045.

Botstein D, White RL, Skolnick M, Davis RW. 1980. Construction of a genetic linkage map in man using restriction fragment length polymorphisms. American Journal of Human Genetics 32, 314-331.

Bouzat JL, Cheng HH, Lewin HA, Westemeier RL, Brawn JD, Paige KN. 1998. Genetic evaluation of a demographic bottleneck in the greater prairie chicken. 
Conservation Biology 12, 836-843.

Ciofi C, Milinkovitch MC, Gibbs JP, Caccone A, Powell JR. 2002. Microsatellite analysis of genetic divergence among populations of giant Galápagos tortoises. Molecular Ecology 11, 2265-2283.

De Ponte Machado M, Feldheim AK, Sellas AB, Bowie RCK. 2009. Development and characterization of microsatellite loci from the Great White Pelican (Pelecanus onocrotalus) and widespread application to other members of the Pelecanidae. Conservation Genetics 10, 1033-1036.

Engel SR, Linn RA, Taylor JF, Davis SK. 1996. Conservation of microsatellite loci across species of Artiodactyls: implications for population studies. Journal of Mammalogy 77, 504-518.

Evanno G, Regnaut S, Goudet J. 2005. Detecting the number of clusters of individuals using the software STRUCTURE: a simulation study. Molecular Ecology 14, 2611-2620.

Falush D, Stephens M, Pritchard JK. 2003. Inference of population structure using multilocus genotype data: linked loci and correlated allele frequencies. Genetics 164, $1567-1587$.

Fernández J, Villanueva B, Pong-Wong R, Toro MA. 2005. Efficiency of the use of pedigree and molecular marker information in conservation program. Genetics 170, $1313-1321$.

Frankham R, Ralls K. 1998. Conservation biology: Inbreeding leads to extinction. Nature 392, 441-442.

Galbusera P, Van Dongen S, Matthysen E. 2000. Cross-species amplification of microsatellite primers in passerine birds. Conservation Genetics 1, 163-168.

Guo SW, Thompson EA. 1992. Performing the exact test of Hardy-Weinberg proportions for multiple alleles. Biometrics 48, 361-372. 
Hampton JO, Spencer PBS, Alpers DL, Twigg LE, Woolnough AP, Doust J, Higgs T, Pluske J. 2004. Molecular techniques, wildlife management and the importance of genetic population structure and dispersal: a case study with feral pigs. Journal of Applied Ecology 41, 735-743.

He LP, Wan QH, Fang SG, Xi YM. 2006. Development of novel microsatellite loci and assessment of genetic diversity in the endangered crested ibis, Nipponia nippon. Conservation Genetics 7, 157-160.

Henkel JR, Jones KL, Hereford SG, Savoie ML, Leibo SP, Howard JJ. 2012. Integrating microsatellite and pedigree analyses to facilitate the captive management of the endangered Mississippi sandhill crane (Grus canadensis pulla ). Zoo Biology 31, 322-335.

Hickman CR, Peters MB, Crawford NG, Hagen C, Glenn TC, Somers CM. 2008. Development and characterization of microsatellite loci in the American white pelican (Pelecanus erythrorhynchos). Molecular Ecology Resources 8, 1439-1441.

Hubisz MJ, Falush D, Stephens M, Pritchard JK. 2009. Inferring weak population structure with the assistance of sample group information. Molecular Ecology Resources 9, 1322-1332.

International Union for Conservation of Nature (IUCN). 2012. IUCN Red List of Threatened Species, Version 2012. 2 [homepage on the Internet]. International Union for Conservation of Nature, Gland, Switzerland; [cited 1 April 2013]. Available from URL: http://www.iucnredlist.org/

Jarne P, Lagoda PJL. 1996. Microsatellites, from molecules to populations and back. Trends in Ecology \& Evolution 11, 424-429.

Ji YJ, Liu YD, Ding CQ, Zhang DX. 2004. Eight polymorphic microsatellite loci for the critically endangered crested ibis, Nipponia nippon (Ciconiiformes: Threskiornithidae). Molecular Ecology Notes 4, 615-617. 
Kohn MH, Murphy WJ, Ostrander EA, Wayne RK. 2006. Genomics and conservation genetics. Trends in Ecology \& Evolution 21, 629-637.

Lande R. 1988. Genetics and demography in biological conservation. Science 241, $1455-1460$.

Nei M. 1987. Molecular Evolutionary Genetics. Columbia University Press, New York.

Park SDE. 2001. Trypanotolerance in west African cattle and the population genetic effects of selection. Dissertation, Trinity College, University of Dublin, Ireland.

Pritchard JK, Stephens M, Donnelly P. 2000. Inference of population structure using multilocus genotype data. Genetics 155, 945-959.

Primmer CR, Moller AP, Ellegren H. 1996. A wide-range survey of cross-species microsatellite amplification in birds. Molecular Ecology 5, 365-378.

Primmer CR, Painter JN, Koskinen MT, Palo JU, Merilä J. 2005. Factors affecting avian cross-species microsatellite amplification. Journal of Avian Biology 36, 348-360.

Primmer CR, Raudsepp T, Chowdhary BP, Moller AP, Ellegren H. 1997. Low frequency of microsatellites in the avian genome. Genome Research 7, 471-482.

Raymond M, Rousset F. 1995. GENEPOP (version 1.2): population genetics software for exact tests and ecumenicism. Journal of Heredity 86, 248-249.

Rice W. 1989. Analyzing tables of statistical tests. Evolution 43, 223- 225.

Sawyer GM, Benjamin RC. 2006. Isolation and characterization of microsatellite loci for parentage assessment in captive populations of roseate spoonbill (Ajaia ajaja). Molecular Ecology Notes 6, 677-679.

Shephard JM, Galbusera P, Hellemans B, Jusic A, Akhandaf Y. 2009. Isolation and characterization of a new suite of microsatellite markers in the European White Stork, Ciconia ciconia. Conservation Genetics 10, 1525-1528. 
Sibley CG, Ahlquist JE. 1990. Phylogeny and Classification of Birds: A study in Molecular Evolution. Yale University Press, New Haven.

Slate J, Coltman DW, Goodman SJ, Maclean I, Pemberton JM, Williams JL. 1998. Bovine microsatellite loci are highly conserved in red deer (Cervus elaphus), sika deer (Cervus nippon) and soay sheep (Ovis aries). Animal Genetics 29, 307-315.

Tarr CL, Conant S, Fleischer RC. 1998. Founder events and variation at microsatellite loci in an insular passerine bird, the Laysan finch (Telespiza cantans). Molecular Ecology 7, 719-731.

Tomasulo-Seccomandi AM, Schable NA, Bryan AL, Brisbin IL, Lama SND, Glenn TC. 2003. Development of microsatellite DNA loci from the wood stork (Aves, Ciconiidae, Mycteria americana). Molecular Ecology Notes 3, 563-566.

Urano K, Tsubono K, Taniguchi Y, Matsuda H, Yamada T, Sugiyama T, Homma K, Kaneko Y, Yamagishi S Iwaisaki H. 2013. Genetic diversity and structure in the Sado captive population of the Japanese crested ibis. Zoological Science (in press).

Urano K, Yamada T, Taniguchi Y, Iwaisaki H, Sugiyama T, Homma K, Kaneko Y, Yamagishi S. 2011. Non-invasive sampling technique for DNA extraction from captive Japanese crested ibis on Sado Island. Animal Science Journal 82, 616-619.

Vernesi C, Crestanello B, Pecchioli E, Tartari D, Caramelli D, Hauffe H, Bertorelle G. 2003. The genetic impact of demographic decline and reintroduction in the wild boar (Suss crofa): a microsatellite analysis. Molecular Ecology 12, 585-595.

Yeung CKL, Hsu YC, Yao CT, Li SH. 2009. Isolation and characterization of 23 microsatellite loci in the black-faced spoonbill (Platalea minor) and amplification in other Ciconiiformes waterbirds. Conservation Genetics 10, 1081-1084.

Zhang DX, Hewitt GM. 2003. Nuclear DNA analyses in genetic studies of populations: practice, problems and prospects. Molecular Ecology 12, 563-584. 


\section{$1 \quad$ Figure Legends}

Fig. 1 Nucleotide sequence alignment of the two PCR products by primers PM1-17 (a) and PM2-37 (b). The upper and lower rows show the sequence of the one and the other PCR product, respectively.

Fig. 2 Genetic structure of the Japanese population in Japan consisting of the 5 founders and 138 descendants based on the STRUCTURE software with 17 markers. Each animal is represented by a single vertical line divided into $\mathrm{K}=2$ colors, where $\mathrm{K}$ is the number of clusters assumed and the length of the colored segment represents the individual's estimated proportion of membership to a particular cluster. The characters A to $\mathrm{E}$ indicate the 5 founders. Among the 10 runs carried out for $\mathrm{K}=2$, only the graphical representation of the highest estimates for $\operatorname{Ln} \operatorname{Pr}(\mathrm{X} / \mathrm{K})$ value is given.

Fig. 3 STRUCTURE result obtained with 13 markers, removing 4 triallelic markers from the whole 17 markers. Each animal is represented by a single vertical line divided into $K=2$ colors and the length of the colored segment represents the individual's estimated proportion of membership to a particular cluster. The characters A to E indicate the 5 founders. 


\section{Fig.1(a)}

CCTCCTTCTGGTCCCTCCCGAATATTTATTTTCTTTCTTTCTTTCTTTCTTTCTTTCTTTCTTTCTTTCTTTCTTTCTTTCTTTCTTTCT

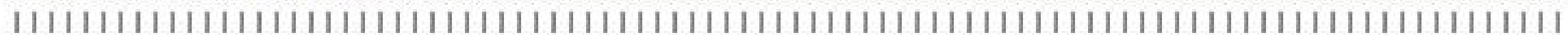
CCTCCTTCTGGTCCCTCCCGAATATTTATTTTCTTTCTTTCTTTCTTTCTTTCTTTCTTTCTTTCTTICTTTCTTTCTTTCTTTCTTTCT

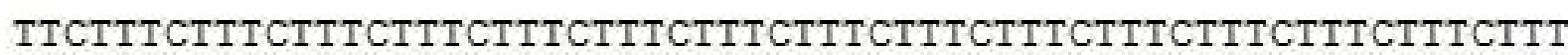
СтTтстттсттстTт

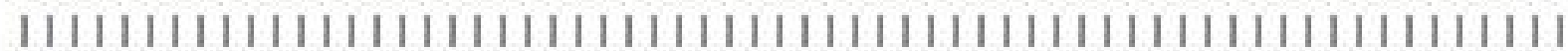
॥ा। $\|1\|\|\|, \|$

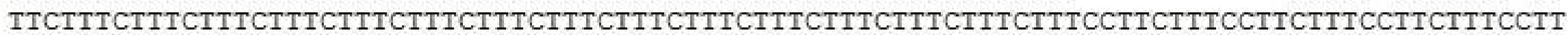
стттссттстттссттстттссттстттссттстттссттссттссттстттссттссттстTт-

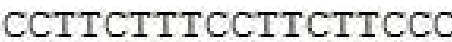
IIIIIIIIIIIIIIIIII IIIIIIIIIIIIIIII IIIIIIIIII IIIIIIIII \|\|\|\|\|\|\|\|$\||| \mid$

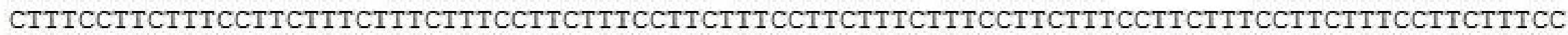
ттстттссттстттссттстттстттссттстттсттт

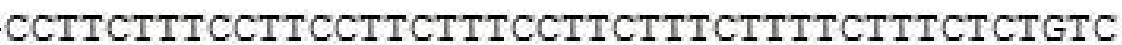

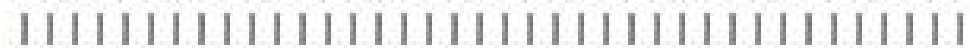
111\|\|\|\|\|\|\|\|\|\|$\|1\|\|\|\|\|\|\|\|\|\|\|\|\| \|$

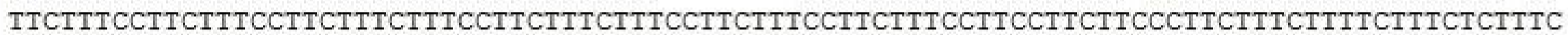
TGTCTCTCTTTCTCTCTCTTCCTCTCTTCCCATATTGATTGTAAAATTATGAGTCTACAGCACGAGCAACTCTGCAG IIIIIIIIIIIIIIIIIIIIIIIIIIIIIII IIIIIIIIIIIIIIIIIIIIIIIIIIIIIIIIII TGTCTстстTTCTCTCTCTTCCTCTCTTCCCATATTTATTGTAAAATTATGAGTCTACAGCACGAGCAACTCTGCAG 


\section{Fig.1(b)}

CATACAAGCAATGCCTAACCATACCTCTGAGTTTCATGTATGTAGATAGATTTCCCTTCTCTTAGAAATGGAGGTTAAGTGTTGTCCAAA

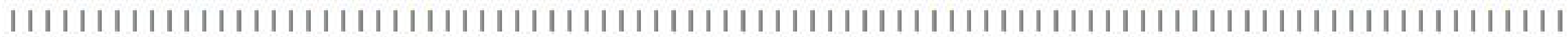
CATACAAGCAATGCCTAACCATACCTCTGAGTTTCATGTATGTAGATAGATTTCCCTTCTCTTAGAAATGGAGGTTAAGTGTTGTCCAAA

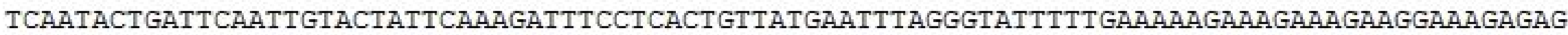

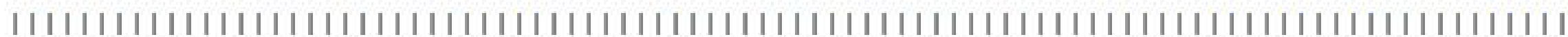
TCAATACTGATTCAATTGTACTATTCAAAGATTTCCTCACTGTTATGAATTTAGGGTATTTTTGAAAAAGAAAGAAAGAAGGAAAGAGAG

AgaAagaAagaAagaAcGaAagaAcGaAagaAC A.AAagaAagaAagaAtgaAag

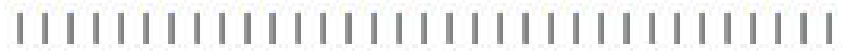
||||||||||||||||||

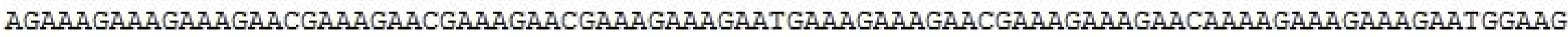

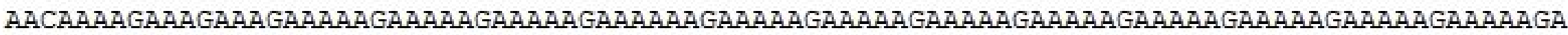
|||||||||||||||||||||||||||||||||||||||||||||||||||||||||||||||||||||||||||||||||||| $\mid$

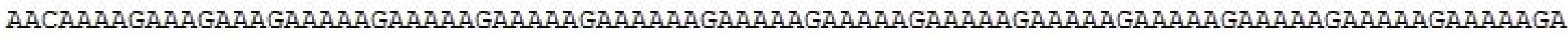

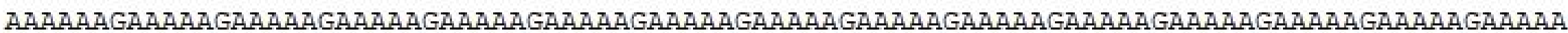
||||||||||||||||||||||||||||||||||||||||||||||||||||||||||||||||||||||||||||||||||

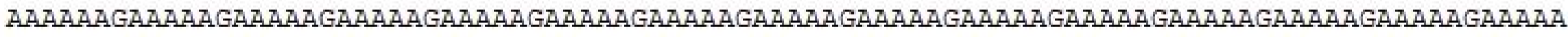

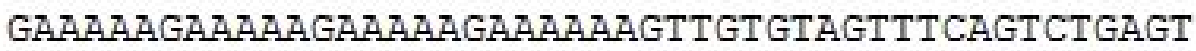

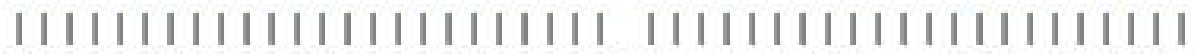

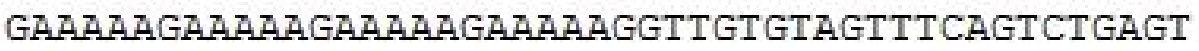


Table 1 The size of PCR products for 5 founders

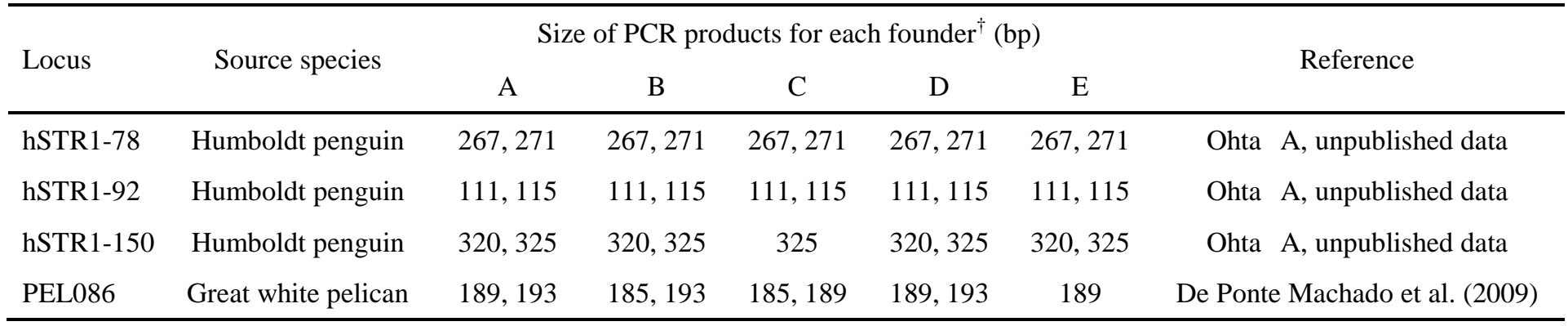

${ }^{\dagger}$ The characters A to E represent founders. 
Table 2 The repeat motif and the number of repeat unit of 2 or 3 alleles for each loci

\begin{tabular}{lccc}
\hline Locus & $\begin{array}{c}\text { Repeat motif of } \\
\text { original species }\end{array}$ & Repeat motif $^{\dagger}$ & $\begin{array}{c}\text { Number of } \\
\text { repeat motif }^{\dagger}\end{array}$ \\
\hline PM1-17 & AAAG & - & - \\
PM2-16 & AAAG & (TTTA)n & $\mathrm{n}=6$ or 7 \\
PM2-20 & AAAG & (AAAG)n & $\mathrm{n}=12$ or 13 \\
PM2-21 & AAAG & (GGAAGAAA)n & $\mathrm{n}=12,14$ or 17 \\
PM2-28 & AAAG & (AAAG)n & $\mathrm{n}=6$ or 7 \\
PM2-29 & AAAG & (AAAG)n & $\mathrm{n}=13$ or14 \\
PM2-37 & AAAG & - & - \\
PM3-13 & CA & (CA)n & $\mathrm{n}=5$ or 6 \\
Aaju02 & (AACT)13TA(CTTT)6 & (CTTTT)mCTTTTT & $\mathrm{m}=20$ and $\mathrm{n}=2$ or \\
Wsu13 & CT(CTTT)3 & (CTTTT)n & $\mathrm{m}=23$ and $\mathrm{n}=1$ \\
hSTR1-78 & AC & (AC)n & $\mathrm{n}=13$ or 14 \\
hSTR1-150 & AC & (CAAA)n & $\mathrm{n}=3$ or 4 \\
PEL086 & TATCC & (AGAAC)n & $\mathrm{n}=4$ or 5 \\
\hline
\end{tabular}

†The characters " $\mathrm{m}$ ” and "n” represent the number of repeat unit. 
Table 3 Allelic diversity (A), genotypes of the 5 individuals, effective number of alleles $\left(\mathrm{n}_{\mathrm{e}}\right)$, unbiased expected heterozygosity $\left(\mathrm{H}_{\mathrm{E}}\right)$, observed (direct count) heterozygosity $\left(\mathrm{H}_{\mathrm{O}}\right)$, polymorphic information content (PIC) and deviation from HWE in the Japanese population (the founders and descendants) of 22 microsatellite markers

\begin{tabular}{|c|c|c|c|c|c|c|c|c|c|c|c|}
\hline \multirow[t]{2}{*}{ Locus } & \multirow{2}{*}{$\begin{array}{l}\text { Allelic } \\
\text { diversity }\end{array}$} & \multicolumn{5}{|c|}{ Genotype of founder ${ }^{\dagger}$} & \multirow{2}{*}{$\mathrm{n}_{\mathrm{e}}$} & \multirow{2}{*}{$\mathrm{H}_{\mathrm{E}}$} & \multirow{2}{*}{$\mathrm{H}_{\mathrm{O}}$} & \multirow{2}{*}{ PIC } & \multirow{2}{*}{$\mathrm{HWE}^{\ddagger}$} \\
\hline & & A & B & C & $\mathrm{D}$ & E & & & & & \\
\hline Nn01 & 3 & 12 & 12 & $13^{*}$ & 12 & 11 & 2.01 & 0.50 & 0.53 & 0.45 & \\
\hline Nn04 & 2 & 12 & 22 & 12 & 12 & 12 & 1.90 & 0.47 & 0.54 & 0.36 & \\
\hline Nn12 & 3 & 13 & 23 & 23 & 12 & 13 & 2.98 & 0.67 & 0.72 & 0.59 & \\
\hline Nn17 & 2 & 22 & 22 & 22 & 22 & $1 * 2$ & 1.02 & 0.02 & 0.02 & 0.02 & \\
\hline Nn18 & 2 & 22 & 12 & 12 & 22 & 12 & 1.43 & 0.30 & 0.33 & 0.26 & \\
\hline Nn21 & 2 & 12 & 11 & 12 & 22 & 12 & 1.99 & 0.50 & 0.58 & 0.37 & \\
\hline Nn25 & 2 & 12 & 12 & 22 & 22 & 12 & 1.87 & 0.47 & 0.43 & 0.36 & \\
\hline Nn26 & 2 & 11 & 12 & 12 & 12 & 12 & 1.63 & 0.39 & 0.46 & 0.31 & $*$ \\
\hline NnNF5 & 2 & 12 & 22 & 12 & 22 & 12 & 1.57 & 0.37 & 0.48 & 0.30 & ${ }^{*},(*)$ \\
\hline PM1-17 & 2 & 11 & 12 & 12 & 12 & 12 & 1.91 & 0.48 & 0.51 & 0.36 & \\
\hline PM2-16 & 2 & 11 & 12 & 11 & 22 & 22 & 1.36 & 0.26 & 0.28 & 0.23 & \\
\hline PM2-20 & 2 & 11 & 12 & 11 & 12 & 11 & 1.25 & 0.20 & 0.16 & 0.18 & $*$ \\
\hline PM2-21 & 3 & 13 & 12 & 11 & 12 & 13 & 2.39 & 0.58 & 0.58 & 0.50 & \\
\hline PM2-28 & 2 & 11 & 12 & 12 & 12 & 12 & 1.69 & 0.41 & 0.46 & 0.32 & \\
\hline PM2-29 & 2 & 12 & 22 & 12 & 22 & 22 & 1.80 & 0.45 & 0.42 & 0.35 & \\
\hline PM2-37 & 2 & 22 & 22 & 22 & $1 * 2$ & 22 & 1.01 & 0.01 & 0.01 & 0.01 & \\
\hline PM3-13 & 2 & $1 * 2$ & 22 & 22 & 22 & 22 & 1.21 & 0.17 & 0.19 & 0.16 & \\
\hline Aaju02 & 2 & 22 & 12 & 12 & 22 & 12 & 1.80 & 0.45 & 0.40 & 0.35 & \\
\hline Wsu13 & 2 & 11 & 11 & 12 & 12 & 11 & 1.31 & 0.24 & 0.28 & 0.21 & \\
\hline hSTR1-78 & 2 & 12 & 12 & 12 & 12 & 12 & 1.66 & 0.40 & 0.44 & 0.32 & \\
\hline hSTR1-150 & 2 & 12 & 12 & 22 & 12 & 12 & 1.49 & 0.33 & 0.33 & 0.28 & \\
\hline PEL086 & 3 & 13 & 23 & 12 & 23 & 22 & 2.83 & 0.65 & 0.67 & 0.57 & \\
\hline Mean & 2.18 & & & & & & 1.73 & 0.38 & 0.40 & 0.31 & $*$ \\
\hline
\end{tabular}

${ }^{\dagger}$ The number 1, 2, 3 represents each allele, the allele specifically carried by one founder is indicated by asterisk, and the genotype specifically carried is indicated in bold.

${ }^{\ddagger}$ Significant deviation from Hardy-Weinberg equilibrium is indicated by asterisk $(P<0.05)$, and that after correction using Bonferroni procedure is indicated by asterisk in bracket $(P<$ $0.05 / 22=0.002)$. 